\title{
HIV-1 Associated Dementia: Clinical Features and Pathogenesis
}

\author{
Christopher Power and Richard T. Johnson
}

\begin{abstract}
HIV-1 infection is characterized by multiple neurological syndromes occuring at all stages of infection. HIV-1-associated dementia, however, is the most devastating CNS consequence of AIDS because of its poor prognosis and functional impairment. A clinical triad of progressive cognitive decline, motor dysfunction, and behavioural abnormalities typifies this subcortical dementia which eventually affects 15 to $20 \%$ of AIDS patients. Neuroimaging, CSF studies and neuropsychological testing are frequently required in diagnosing HIV-associated dementia, to exclude other conditions including psychiatric illnesses, opportunistic diseases and systemic disorders. The pathogenesis of HIV dementia is uncertain and there is evidence that multiple mechanisms of neurological injury occur. These mechanisms include: the role of neurovirulent strains of HIV; the potential neurotoxicity of HIV gp 120, nitric oxide and quinolinic acid; immunologically mediated CNS injury through the action of cytokines and arachidonic acid metabolites; and altered bloodbrain barrier permeability. A collective approach involving clinical studies, in vitro assays and animal models will provide greater insight into the pathogenesis and the rational development of therapy for HIV dementia.
\end{abstract}

RÉSUMÉ: La démence associée à l'infection par le VIH-1: manifestations cliniques et pathogenèse. L'infection par le VIH-l est caractérisée par des syndromes neurologiques variés survenant à tous les stages de l'infection. Cependant, la démence associée au VIH-I(DVIH) est la conséquence la plus dévastatrice du SIDA au niveau du SNC à cause de son pronostic sombre et de ses répercussions fonctionnelles. La triade clinique constituée d'un déclin cognitif progressif, de dysfonction motrice et d'anomalies du comportement est typique de cette démence sous-corticale qui touche de 15 à $20 \%$ des patients atteints du SIDA au cours de leur maladie. L'imagerie du SNC, l'examen du LCR et les épreuves neuropsychologiques sont souvent requises pour poser un diagnostic de DVIH afin d'exclure une maladie psychiatrique, une infection opportuniste ou une maladie systémique. La pathogenèse de la DVIH est mal connue et, selon certaines données, plusieurs mécanismes sont en cause, incluant le rôle de souches neurovirulentes du VIH, la neurotoxicité possible de la gpl20 du VIH, de l'oxyde nitrique et de l'acide quinolinique, l'atteinte du SNC à médiation immunitaire par les cytokines et les métabolites de l'acide arachidonique et une altération de la perméabilité de la barrière hémato-encéphalique. Une approche globale impliquant des études cliniques, des études in vitro et des modèles animaux permettra d'élucider sa pathogenèse et de développer un traitement de la DVIH.

Can. J. Neurol. Sci. 1995; 22: 92-100

Over the past decade, the AIDS pandemic has rapidly expanded worldwide resulting in at least 13 million people being currently infected with either HIV-I or HIV-2.' Both HIV-1 and HIV-2 belong to the lentivirus family of retroviruses and like other lentiviruses such as simian and feline immunodeficiency viruses, are characterized by persistent infection and immune deficiency resulting in death. ${ }^{2-5}$ Although both HIV-1 and HIV-2 are associated with immune suppression and CD4-positive lymphocyte depletion, HIV1 appears to be more virulent, causing a more rapid progression of disease, has a wider geographical distribution, generates a broader genetic diversity and possibly is associated with a larger range of clinical phenotypes although the neurological syndromes accompanying HIV-2 infection have not been clearly defined. ${ }^{6-10}$ Early in the AIDS epidemic it was apparent that neurological disease was a common feature at all stages of HIV-I infection in both children and adults. ${ }^{11-13}$ The spectrum of neurologic disease occurring in AIDS encompasses both primary HIV-induced illnesses such as aseptic meningitis, vacuolar myelopathy, diverse peripheral neuropathies, and HIV dementia (Figure 1) as well as secondary or opportunistic illnesses such as cerebral toxoplasmosis, cytomegalovirus (CMV) encephalitis, and cryptococcal menigitis. ${ }^{14}$ HIV-1 associated dementia (HIVD) is one of the most devastating complications of HIV infection because of its poor prognosis and the severity of the patients' functional impairment. Consequently, HIVD has attracted attention because of the severity of clinical illness and the multiple mechanisms of pathogenesis proposed for this profound neurological syndrome. Many of the ideas and experimental techniques derived from the study of AIDS-related neurological diseases are applicable to other neurological diseases such as multiple sclerosis and Alzheimer's disease. ${ }^{15}$ This article outlines the clinical features of HIV dementia and possible pathogenic mechanisms underlying its development.

\footnotetext{
From the Department of Neurology, Johns Hopkins University, Baltimore RECEIVED JUNE 7, 1994. ACCEPTED IN FINAL FORM OCTOBER 18, 1994.

Presented in part as the Francis McNaughton Prize Lecture at the XXIIIrd Canadian Congress of Neurological Sciences, Toronto, June 1993.

Reprint requests to: Dr. C. Power, Section of Neurology, Department of Internal Medicine, University of Manitoba, GF 543, Hẹalth Sciences Centre. 700 William Strect, Winnipeg, Maniboba, Canada R3E 0Z3
} 


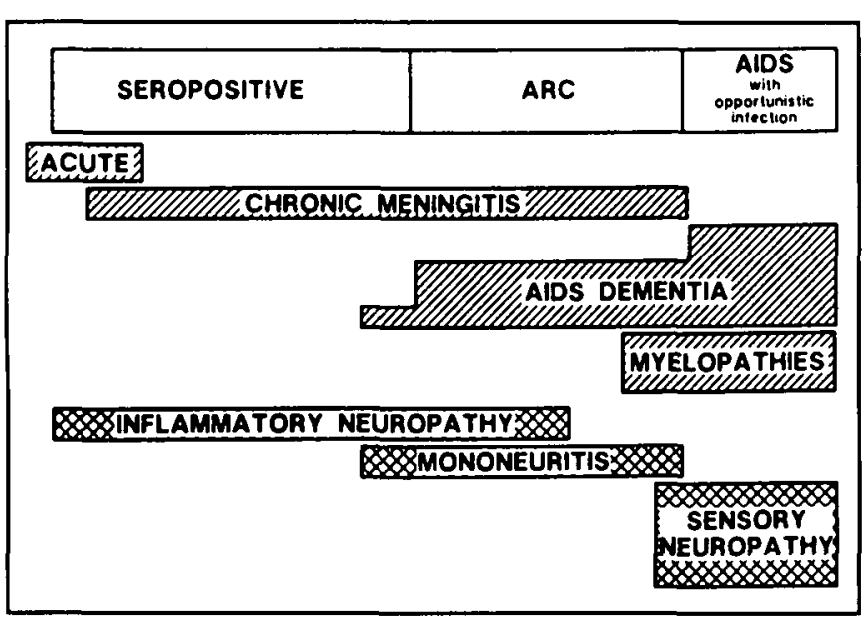

Figure I: HIV-I is associated with neurological diseases at all stages of infection and at all levels of the nervous system (reprinted by permission). ${ }^{14}$

\section{Cinical. Features}

HIV dementia (HIVD) ${ }^{16}$ which has also been termed HIV-1 associated dementia complex ${ }^{17}$ or AIDS dementia complex ${ }^{18}$ is characterized by a clinical triad of cognitive impairment, motor dysfunction and behavioural abnormalities. ${ }^{16.19}$ The onset of HIVD is the first AIDS-defining illness in 3\% of HIV-infected patients, but most of these patients also have CD4 levels of 200 cells $/ \mathrm{mm}^{3}$ or less. ${ }^{20}$ It is noteworthy that cognitive impairment in the pre-symptomatic stages of HIV-I infection is not widespread or a requisite feature of HIV infection, ${ }^{21-23}$ contrary to early reports of widespread neuropsychological deficits in pre-AIDS patients. Eventually, HIVD affects $15-20 \%$ of all patients with AIDS and is associated with a worsened prognosis with a mean survival time of 7 months. ${ }^{24}$ HIVD is a subcortical dementia presenting with memory loss, depressive symptoms, apathy, withdrawal from routine activities, and occasionally psychosis. ${ }^{16.19}$ In the early stages of dementia, it is often difficult to distinguish this syndrome from psychiatric illness or opportunistic infections of the CNS. The clinical diagnosis of HIVD thus may require extensive history taking from family members or friends, psychiatric and/or neuropsychological evaluations, CSF and radiological studies. The physical examination in patients with HIVD is notable for psychomotor slowing, hyperreflexia, hypertonia, ataxia, release signs, impaired rapid movements and an accompanying myelopathy. Diagnostic criteria recommended by the American Acadeny of Neurology ${ }^{17}$ for HIV dementia include: 1) HIV-1 seropositivity; 2) history of progressive cognitive and behavjoral decline; 3) neurological and/or neuropsychological evaluation consistent with decline from premorbid baseline; and 4) CNS opportunistic processes excluded by CT or MR imaging and CSF analysis. The syndrome demonstrates a marked diversity in its rate of advancement, as shown in Figure 2, but the factors that determine this variability in the disease course are uncertain. Cognitive slowing and ataxia may progress to complete mutism and paraparesis with fecal and urinary incontinence. The severity of cognitive and motor impairment can be staged using Memorial Sloan-Kettering (MSK) scale which assesses a patient's functional impairment. ${ }^{25}$ The MSK scale ranges from mild dementia or minimal cognitive and motor deficits (MSK $=1$ ) to severe dementia or end-stage vegetative state $(\mathrm{MSK}=4)$.

\section{Neuropsychology}

HIV dementia has a characteristic neuropsychological profile with progressive decline in performance in, at least, two areas

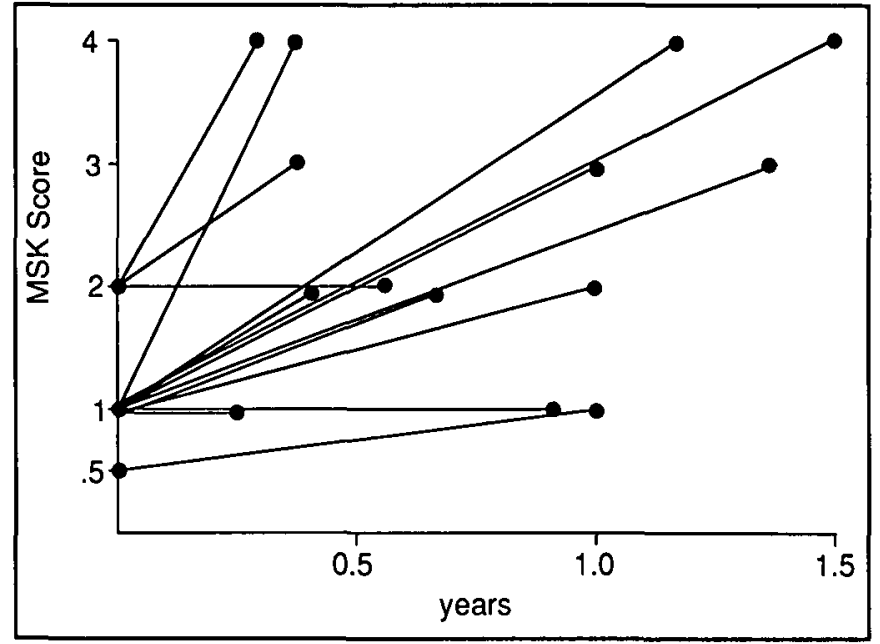

Figure 2: Variation in disease progression in patients with HIVD. Individual HIVD patient's disease course is represented by a line indicating MSK scores plotted versus time for the initial and final evaluations. The clinical status of each patient was assessed at the time of initial diagnosis of HIVD and the final evaluation before death.

including motor speed, nonverbal memory and frontal lobe tasks. ${ }^{26}$ Because it is essential to diagnose an altered mental status in AIDS patients as early as possible and neuropsychological testing is not universally available, a brief quantitative diagnostic test was developed, the HIV Dementia Scale (HDS), ${ }^{27}$ to be used in conjunction with other diagnostic tests. This scale tests specific abilities including timed motor tasks, frontal lobe functions and memory that are impaired early in HIV infection (Figure 3). The HDS is easily administered at the bedside with superior sensitivities and specificities to other short mental status assessments such as the Minimental Status Examination. ${ }^{28,29}$ This test may also be of value in following patients' cognitive status over time and response to therapy.

\section{Laboratory Investigations}

Additional diagnostic tests include CSF and radiological studies to rule out other causes of altered mental status. However nonspecific abnormalities may occur in some patients with HIV dementia including elevated p24 levels, total protein $(60 \%), \mathrm{IgG}$ fraction (80\%), oligoclonal bands (35\%) and a lymphocytosis with CD4/CD8-positive cell ratios in CSF that mirror those in peripheral blood. ${ }^{16.30 .31}$ Radiological features of HIVD include diffuse cerebral atrophy and white matter rarefaction. ${ }^{12.32}$ Both SPECT and EEG show nonspecific abnormalities in some patients with HIV demen$\mathrm{tia}^{33,34}$ and thus have not been used routinely for clinical evaluation. Table 1 outlines key features that suggestive of the diagnosis of HIV dementia.

\section{Differential Diagnosis}

The differential diagnosis for HIVD includes psychiatric illnesses, CNS opportunistic infections and neoplasms, and systemic disorders. Depression and psychosis can be mistakenly diagnosed in patients with HIVD and thus psychiatric and neuropsychological evaluations are often helpful. CNS opportunistic and neoplastic diseases to be ruled out include cerebral toxoplasmosis, cryptococcal meningitis, progressive multifocal leucoencephalopathy, CNS lymphoma, and cytomegalovirus encephalitis (CMVE). Radiological and CSF analyses show specific changes that identify the former four conditions, however CMVE may be more difficult to diagnose. A rapid downhill course, prominent systemic CMV infection, 


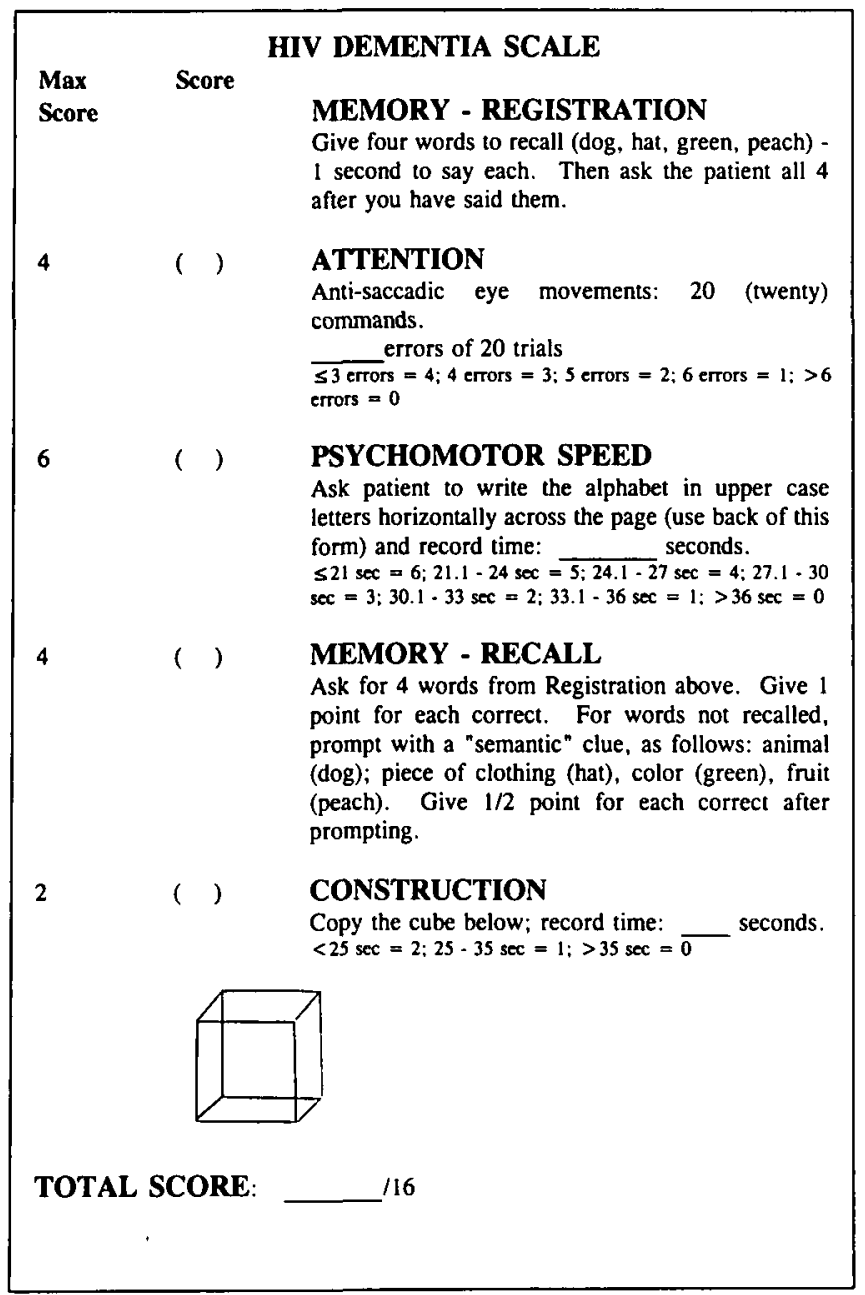

Figure 3: The HIV dementia scale (HDS) was designed to provide a brief and easily administered diagnostic test that demonstrates superior sensitivity and specificity to other bedside tests. A score of $\leq 10$ is indicative of HIVD (reprinted by permission). ${ }^{27}$

hyponatremia, CMV genome detection in CSF by the polymerase chain reaction (PCR), and characteristic periventricular lesions on CT or MRI scans help to distinguish CMVE from HIVD. ${ }^{35}$ Other common systemic complicating conditions such as hypoxia, intoxicants and renal or hepatic failure require investigation and exclusion before the diagnosis of HIVD may be made.

\section{Neuropathology}

Pathological features of HIV dementia observed by histopathological methods are striking for the lack of correlation between the severity of dementia and the inflammatory pathological changes. ${ }^{18.36 .37}$ Asymptomatic HIV-infected individuals may show mild pathological changes and HIV antigens in the CNS early in infection. ${ }^{38.39}$ AIDS patients with and without HIV dementia may manifest HIV encephalitis which is defined by multiple foci of multinucleated giant cells and microglial nodules and/or HIV antigens and genome. ${ }^{40-42}$ However other neuropathological features including diffuse myelin pallor and neocortical neuronal drop out have been observed more frequently in AIDS patients with dementia. ${ }^{18,36.43 .44}$ Most patients with multinucleated giant cells and diffuse myelin pallor have HIVD although $50 \%$ of HIVD patients have neither multinucleated giant cells nor diffuse myelin pallor. ${ }^{36}$ In addi-
Table 1: Clinical features suggestive of HIV dementia.

1. HIV-1 seropositivity and CD4 level $\leq 200 \mathrm{cells} / \mathrm{mm}^{3}$.

2. History of progressive subacute mental decline: apathy, memory loss, and slowed cognition.

3. Physical findings include slowed limb and eye movements, hyperreflexia, hypertonia, release signs and an HDS score of $\leq 10$.

4. Neuropsychological testing demonstrates worsening performance in at least two areas including frontal lobe tasks, motor speed, and nonverbal memory.

5. CSF studies show elevated $\mathrm{p} 24, \operatorname{IgG}$, and protein levels and the absence of other infections, i.e., cryptococcus and syphilis.

6. Cranial imaging reveals cerebral atrophy and white matter abnormalities including hyperintensities on MRI and hypodensities on CT; exclusion of opportunistic processes.

7. Exclusion of major psychiatric and metabolic disorders, and substance abuse.

tion to neuronal loss, more sensitive morphological techniques have indicated that a loss of synaptic contacts and vacuolar changes in neurons in both the deep grey matter and cortex occur in patients dying with AIDS..$^{54-56}$ There is a paucity of lymphocytes found in the brains of patients dying with AIDS unlike the CSF in which there is a lymphocytosis; ${ }^{30}$ thus, equating the CSF cell profile with the cell types and degree of inflammation found in the brain in patients with AIDS can be very misleading.

\section{HIV Detection in Brain}

HIV antigens and viral genome can be detected in the brains of AIDS patients, ${ }^{45-47}$ primarily in the deep grey matter and white matter. ${ }^{48} \mathrm{~A}$ definitive correlation between viral burden in the brain and the severity of clinical neurological disease has not yet been shown. In fact, a striking dichotomy exists between the small number of HIV-infected cells and the severity of the clinical phenotype. ${ }^{49}$ The majority of cells infected in the CNS are microglia and perivascular macrophage $\mathrm{s}^{45.50}$ but astrocytes have also been shown to be infected to a lesser extent, especially in children with HIV infection. ${ }^{51.52}$ Endothelia, oligodendrocytes and neurons have not been shown convincingly to be infected by HIV in vivo. The low levels of viral antigen and genome detection in the brains of AIDS patients may reflect the insensistivity of techniques such as immunocytochemistry or in-situ hybridization although newer technologies such as in-situ polymerase chain reaction (PCR) also do not demonstrate high levels of detectable viral genome in AIDS patients with and without HIVD compared to other CNS viral infections. ${ }^{53}$

\section{Treatment}

HIV dementia has been shown to improve transiently with antiretroviral therapy over a short time period. Zidovudine (AZT) appears to ameliorate signs and symptoms in adults with HIVD ${ }^{57-59}$ and children with AIDS-related delayed motor and cognitive development show improved performance with AZT therapy. ${ }^{60}$ Clinical trials testing other therapies including other nucleoside analogs, calcium channel blockers and inhibitors of TNF-alpha synthesis are in progress. The key issue in developing rational therapy for HIVD is a clear understanding of the pathogenesis underlying this clinical 
syndrome but the observation that HIVD is, in part, reversible provides optimism in considering therapeutic interventions.

\section{Pathogenesis}

In attempting to understand the mechanisms underlying the development of CNS disease associated with HIV infection, experimental approaches in the fields of neurobiology, immunology, molecular biology, and virology have been employed. Consequently, numerous hypotheses with supporting data from studies of both animal retrovirus models and humans in addition to in vitro cell culture techniques to explain the pathogenesis of HIVD have emerged over the past ten years. These hypotheses include roles for potential host and viral neurotoxic molecules, ${ }^{61,62}$ immunological molecules that are damaging to the $\mathrm{CNS}^{63,64}$ and the role of distinct viral strains in the development of HIV-related CNS disease. ${ }^{65-69}$ Each of these strategies will be reviewed but it is prudent to bear in mind that there are few correlative data between the results of in vitro assays and in vivo findings to date.

It is widely assumed but not documented that HIV gains access to the brain through infected blood-derived macrophages or monocytes that traverse blood-brain barrier whereupon susceptible adjacent cells (microglia and astrocytes) become infected. This proposed route of infection has been termed the Trojan Horse hypothesis ${ }^{70}$ and is supported by data indicating that many of perivascular cells observed in the brains of AIDS patients are HIVinfected macrophages. ${ }^{45}$ Cellular entry by HIV into blood-derived macrophages and $\mathrm{T}$ cells is dependent on the cell surface molecule, CD4, which acts as a receptor for HIV. ${ }^{71}$ But in the CNS, the picture is more complicated because in addition to CD4, other HIV receptors have been identified including the molecule, galactocerebroside, $^{72}$ and putative receptors on astrocytes ${ }^{73}$ and endothelial cells. ${ }^{74}$

\section{HIV Strain Diversity}

As with other viruses, the envelope protein of HIV participates in cellular entry and influences its tropism or which cells are infected. HIV cell tropism is dependent on specific sequences within the V3 region within the envelope. ${ }^{75.76}$ In the few patients from whom brain-derived HIV envelope sequences including the $V 3$ region were obtained, a striking homogeneity in viral sequences was observed. ${ }^{65-67}$ This finding is in contrast to HIV blood-derived envelope sequences and strains which may vary widely depending on the stage of disease and the individual host. ${ }^{5}$ The brain-derived sequences of HIV resemble macrophage-tropic HIV strains and infection by live brain-derived isolates is restricted to macrophages in vitro. ${ }^{76-78}$ Thus, it is not surprising that principal cell infected in the CNS is the microglia which is of macrophage lineage. Macrophage tropism is, therefore, a necessary feature of an HIV strain to infect the CNS and subsequently cause disease.

Different retroviruses show a marked variation in their ability to infect the CNS (neurotropism) and cause neurological disease (neurovirulence) in animal models. ${ }^{79-82}$ Some animal lentiviruses such as simian immunodeficiency virus and Visna/Maedi are characterised by neurovirulent strains. ${ }^{80.83 .84}$ To address the question of whether there are distinct sequences of HIV that are associated with neurovirulence, i.e., the ability to cause dementia, a study was performed comparing HIV envelope sequences from HIVD and non-demented AIDS patients. ${ }^{85}$ HIV proviral DNA was derived from autopsied brains of HIVD and control non-demented (ND) AIDS patients who were closely followed in the NeuroAIDS clinic premortem at the Johns Hopkins Hospital. The HIVD and ND groups were matched for age, CD4 level, and antiretroviral therapy. Sequence analysis of the $\mathrm{V} 3$ and flanking regions of HIV envelope was performed. The brain-derived HIV sequences from all patients regardless of group resembled previously reported macrophagetropic strains of HIV (Figure 4). Two positions, 305 and 329, in the 143 amino acid fragment encompassing the V3 region showed significant diversity between the two clinical groups (Figure 5). In addition, sequences derived from individuals with HIVD exhibited multiple residues at which unique amino acids relative to the nondemented group were identified. The unique amino acids were more frequently observed in the more severely demented patients. These results indicate that macrophage-tropic strains occur in the brains of all AIDS patients but, in addition, there are distinct HIV sequences related to the clinical development of HIVD. Whether these sequence differences are directly involved in the pathogenesis of

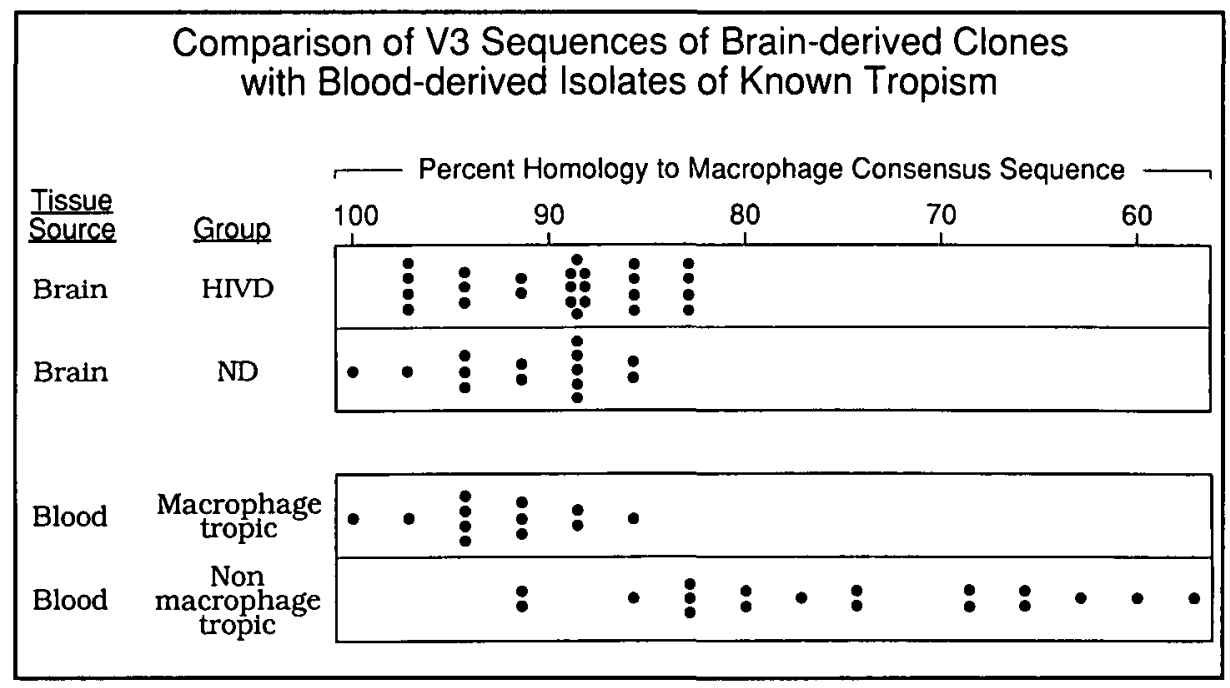

Figure 4: Comparison of the homology of V3 sequences of brain-derived clones and previously reported blood-derived clones and isolates of known tropism with the macrophage tropic consensus sequence. Each dot represents a different clone. Regardless of clinical group (HIVD or ND). brainderived isolates were similar to blood-derived macrophage-tropic isolates and differed significantly from blood-derived nonmacrophage-tropic isolates (reprinted by permission). ${ }^{86}$ 


\begin{tabular}{cccccccccc}
\hline $\begin{array}{c}\text { PATIENT } \\
\text { GROUP }\end{array}$ & \multicolumn{4}{c}{ His } & Ser & Pro & Other & Total & \multicolumn{3}{c}{ LOS } & lle & Other \\
\hline HIVD & 17 & 8 & 0 & 0 & 25 & 15 & 9 & 1 \\
ND & 0 & 3 & 8 & 3 & 14 & 2 & 11 & 1 \\
\hline Database & 20 & 6 & 6 & 27 & 59 & 6 & 41 & 12 \\
\hline
\end{tabular}

Database is from "Human Retroviruses and AIDS 1993", ed. G. Myers et al. The frequency of each amino acid at each position in the HIVD and ND groups was compared individually to the sum of all other amino acid frequencies in separate $2 \times 2$ contingency tables with Fishers Exact Test. The following $\mathrm{P}$ values were observed: His $305(\mathrm{P}<.0001)$, Pro $305(\mathrm{P}<.0001)$, Leu $329(\mathrm{P}=.0078)$, and Ile $329(\mathrm{P}=.0187)$. Boxed values are significantly different between HIVD and ND groups.

Figure 5: Comparison of amino acids at positions 305 and 329 for brain-derived HIV envelope clones (reprinted by permission). ${ }^{86}$

HIVD or merely linked to other neurovirulent genes is unknown, however, it is of interest that peptides made from the V3 and flanking regions have been shown to be not neurotoxic in vitro although peptides derived from HIV strains associated with HIVD have not yet been evaluated. ${ }^{86}$ Tropism studies of recombinant infectious HIV clones bearing the brain-derived $V 3$ regions from patients with and without HIVD revealed that these clones infected only macrophages and microglia, suggesting that HIV macrophagetropism is an essential step in the development of neurovirulence ${ }^{87}$ Further sequence analysis of other regions of the HIV genome and the reconstruction of HIV recombinant clones to be tested in vitro using different genomic regions of HIV may elucidate viral genetic determinants participating in the pathogenesis of HIVD.

\section{Neurotoxicity}

Potential host and viral neurotoxic molecules have been identified in association with HIV infection. ${ }^{88.89}$ The HIV gp 120 envelope protein has been shown to the neurotoxic in different in vitro and in vivo systems. ${ }^{61.90}$ The means of neuronal injury and death may be direct or indirect although it appears to be a excititoxic mechanism, being both calcium-dependent and mediated by glutamate (NMDA) receptors. ${ }^{88}$ $\mathrm{gp} / 20$ neurotoxicity is reduced by both calcium channel blockers and glutamate receptor blockers which has led to a clinical trial in which different calcium channel blockers are being tested therapeutically in patients with HIVD. Other neurotoxic agents have been implicated in the pathogenesis of HIVD including quinolinic acid which is tryptophan-derived and has been shown to be elevated in the CSF of patients with HIVD ${ }^{62}$ and nitric oxide which appears enhance gp 120 neurotoxicity. ${ }^{91}$ Guilian et al. have identified a small molecule $(<5000 \mathrm{kD})$ which has been shown to damage neurons in vitro and is secreted by HIV-infected macrophages and/or macrophages treated with gp 120 peptide. ${ }^{86}$ An indirect mechanism of neurotoxicity seems most plausible in light of the small number of HIV infected cells in the CNS.

\section{Neuroimmunolgy}

Immunological activation is a feature of HIV infection both within and outside the CNS. ${ }^{88.92}$ Astrocytes and microglia appear activated early in infection ${ }^{39.93}$ and different immunological molecules produced by these cell types including cytokines and arachidonic acid metabolites show increased expression in vivo and in vitro in association with HIV infection. ${ }^{64.94-96}$ Wesselingh et al. have reported that increased transcription of TNF-alpha occurs in the brains of patients with HIVD with a strong correlation between level of TNF-alpha mRNA and severity of HIV dementia (Figure 6). ${ }^{64}$ Arachidonic acid metabolites are also elevated in the CSF of patients with HIVD and

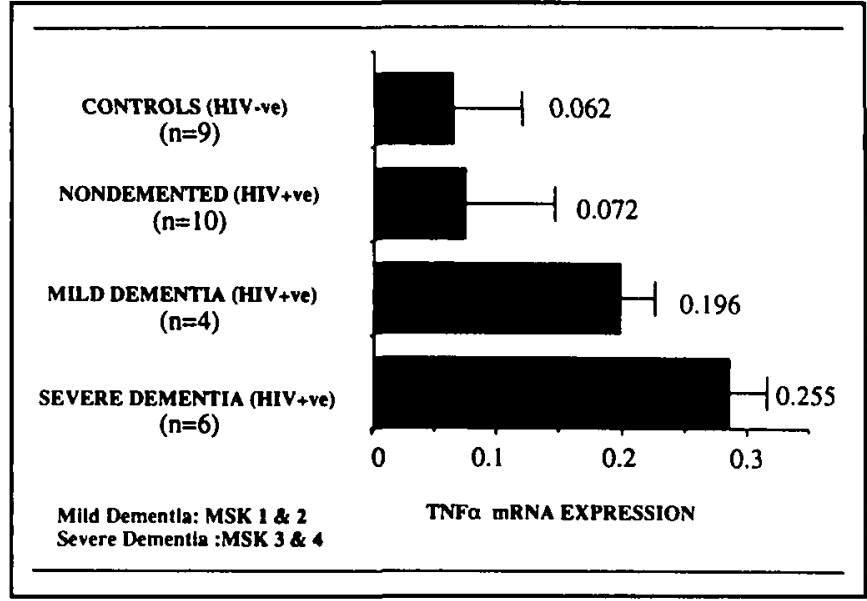

Figure 6: Levels of TNF-alpha mRNA in the brains of AIDS patients are correlated with the clinical development and severity of HIVD (reprinted by permission)..$^{64}$

have been shown to be associated with HIV infection in glial cultures. ${ }^{96.97}$ To examine the influence of host genetic diversity on the susceptibility to immunological activation in the pathogenesis of HIVD, studies of HLA antigen expression in patients with and without HIVD are underway.

\section{Blood Brain Barrier Alteration}

The consequences of immunological activitation within the CNS are diverse. TNF-alpha is known to induce expression of MHC Class I and II expression within the CNS, enhance viral replication and is toxic in glial cultures. ${ }^{88.98}$ In addition, TNF and other cytokines may alter the permeability of the blood-brain barrier (BBB) as observed in other CNS inflammatory diseases. ${ }^{99-101}$ Early reports suggested that the blood brain barrier was more permeable in patients with AIDS. ${ }^{102-104}$ To test the hypothesis that the BBB was more permeable in patients with HIVD compared to HIV seropostive and seronegative patients, a study of age and autopsied-time matched seronegative, preAIDS, and AIDS patients with and without HIVD was performed. ${ }^{93} \mathrm{BBB}$ integrity was analysed by the extrusion of serum proteins into the brain parenchyma. The results of this study indicated that increased BBB permeability occurred in all patients with HIVD but rarely in AIDS patients without HIVD or seronegative controls except in those individuals with some other inflammatory neurological disease (Figure 7). Increased BBB permeability was significantly associated with diffuse myelin pallor on pathological samples and increased signal intensity in white matter of $T_{2}$ weighted MRI scans in patients with HIVD. In patients with HIVD, serum proteins were detected in cortical neurons which exhibited dysmorphic appearances suggesting that these neurons were injured or dying. The mechanism underlying altered bloodbrain barrier permeability is unclear although other groups have identified abnormalities in cerebral endothelia morphology in patients with HIVD. ${ }^{105}$ To examine the expression of different cell adhesion molecules on cerebral endothelia, studies of ICAM-I and VCAM-1 were performed in the same group of patients studied in the BBB permeability analysis. These molecules were chosen because they are known to be induced by cytokines such as TNFalpha, and bind monocytes; thus they may facilitate the CNS entry of potentially HIV-infected macrophages/monocytes. ${ }^{106}$ Detection of ICAM- 1 on cerebral endothelium by immunocytochemistry was significantly greater in AIDS patients compared to seronegative controls although there were no differences between demented and 


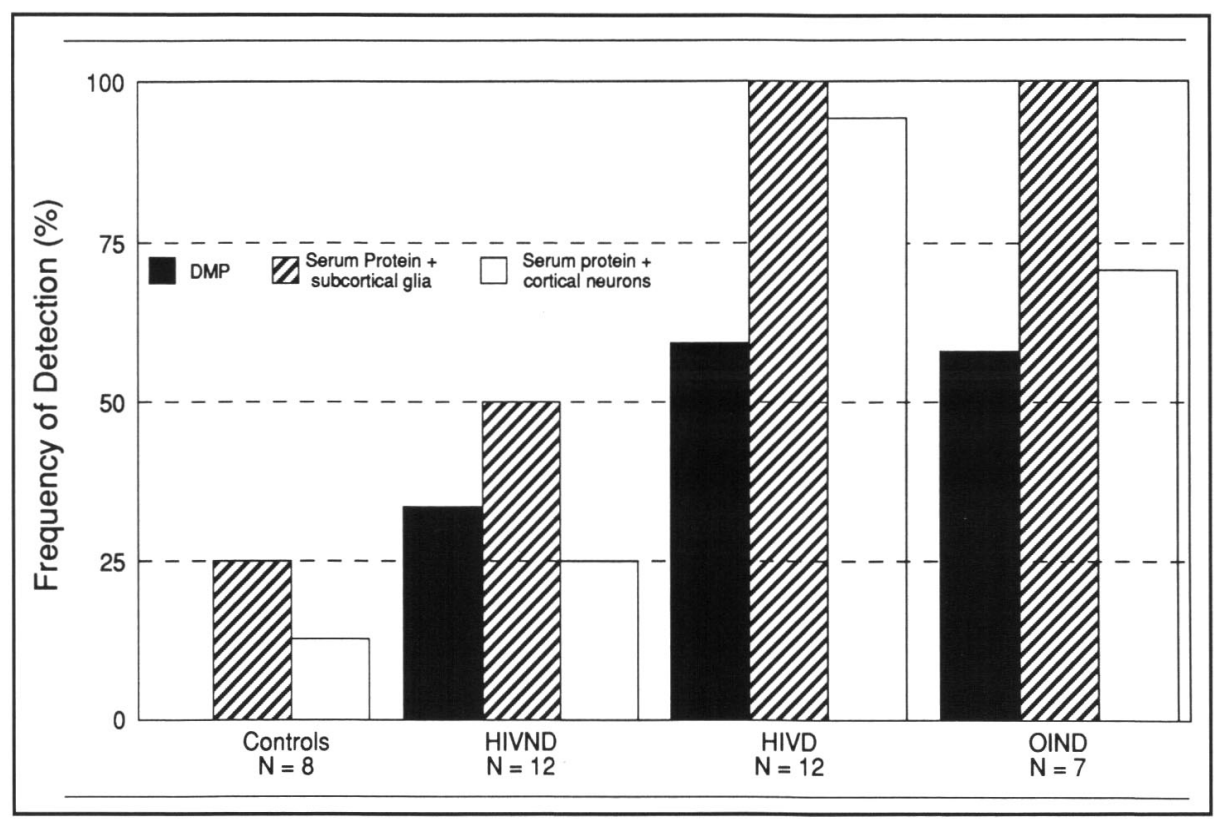

Figure 7: Frequencies of diffuse myelin pallor (DMP), serum protein positive subcortical glia and serum protein positive cortical neumns in HIVseronegative control, AIDS-demented (HIVD) and nondemented (HIVND), and Other Inflammatory Neurological Diseases (OIND) groups. The HIVD group demonstrated a significantly greater frequency of immunostained subcortical glia and cortical neurons compared to the HIVND and control groups. The OIND and HIVD groups did not differ in their frequencies of neuronal or glial immunostaining (reprinted by permission). ${ }^{93}$

nondemented AIDS patients. Surprisingly, VCAM-1 was identified primarily on cells within microglial nodules in patients with AIDS and rarely on cerebral endothelia. ${ }^{107}$ These studies suggest that the expression of certain cell adhesion molecules is enhanced in the CNS of AIDS patients which may be an initial step in the pertubation of the blood brain barrier's permeability although other groups of adhesion molecules such as the cadherins may also be involved. It is clear that immunological factors participate in the development of HIV related CNS disease with significant consequences. However, many questions remain to be answered including the specific mechanism by which different immune molecules cause neurological injury, the extent and mechanisms of immune surveillance of HIV infected cells within the CNS.

\section{Animal Models}

The use of animal models in testing many of the hypotheses presented above has become increasingly important. A variety of models have become popularized over the past decade. SIV infection of macaques and FIV infection of cats, both of which are lentiviruses, produce clinical and pathological neurologic disease. ${ }^{80,84,108}$ Severe combined immune deficient mice (SCID) infected intracranially with HIV display pathological features similar to HIV encephalitis. ${ }^{109}$ Transgenic mice have also been used to study the effects of expression of different HIV genes within the CNS. ${ }^{110.111}$ Of particular interest is the transgenic model in which HIV gp120 expressed under the control of a GFAP promoter. "II In this model, neuronal changes similar to those seen in AIDS patients have been observed although behavioral correlations have not yet been published.

\section{Future Questions}

HIV-related neurological disease has attracted interest from the time of the onset of the pandemic because of its high prevalence among patients with AIDS and the ensuing clues to the development of other neurological diseases. Much of the attention has been directed towards studying the clinical phenomenology and possible pathogenic mechanisms to establish a rational approach to therapy. However, important clinical issues yet to be addressed include the role of drug (AZT) resistance in CNS disease progression, epidemiological analysis of HIV-1 and HIV-2-related neurological diseases in other geographic regions affected by HIV, i.e., Africa and Asia, identification of more specific risk factors and diagnostic tools, and the development and testing of new therapies. Large steps have been made in understanding the pathogenesis of HIVD especially in the areas of immunology and neurotoxicity but a comprehensive understanding is still lacking especially in the area of pediatric HIV-associated neurological disease, likely because of the multiple mechanisms are involved. Many questions remain unanswered concerning the role of CNS viral load in relation to clinical disease, specific mechanisms underlying viral protein- and cytokine-mediated neurologic disease, the existence of other CNS receptors for HIV, host resistance genes, and complementary viruses involved in the pathogenesis of CNS disease as have been observed in animal retroviral diseases. ${ }^{81.112-114}$ A combined approach in the future using in vitro assays correlated with clinical findings, animal models and clinical-pathological studies will provide more insights into the pathogenesis of HIVD and the sound development of new treatments for HIVD. In addition, analysis of viral and host interactions within a comparatively closed system, such as the brain, may provide useful perspicacity into HIV-associated disease in other organ systems. This may be helpful in discerning the interaction between the evolution of HIV virulence and the impact of immunological pressure on the progression of disease. Furthermore, studies of a rapidly mutating pathogen such as HIV in relation to CNS disease may permit a broader understanding of the rules governing neurovirulence that could be applied to the treatment of other CNS viruses such as HTLV-1, Japanese B and Herpes simplex encephalitides. 


\section{ACKNOWLEDGEMENTS}

This work was supported by NINDS NS 26643. Dr. Power is an MRC (Canada) Fellow and the recipient of the 1993 Francis McNaughton Award (Canadian Neurological Society) for clinical research.

\section{REFERENCES}

I. Merson MH. Slowing the spread of HIV: agenda for the 1990s. Science 1993; 260: 1266-1268.

2. Pedersen NC, Ho EW, Brown ML, Yamamoto JK. Isolation of a Tlymphotropic virus from domestic cats with an immunodeficiency-like syndrome. Science 1987; 235: 790-793.

3. Narayan $\mathrm{O}$, Clements JE. Biology and pathogenesis of lentiviruses. J Gen Virol 1989; 70: 1617-1639.

4. Curran JW, Morgan WM, Hardy AM, et al. The epidemiology of AIDS: current status and future prospects. Science 1985; 229: 1352-1357.

5. Myers G, Wain-Hobson S, Korber B, Smith RF. Human Retroviruses and AIDS 1993. A Compilation and Analysis of Nucleic Acid and Amino Acid Sequences. Theoretical Biology and Biophysics Group T-10, 1993; Los Alamos, NM,

6. Clavel F, Guetard D, Brun-Vezinet $F$, et al. Isolation of a new human retrovirus from West African patients with AIDS. Science 1986; 233: 343-346.

7. Clavel F, Mansinho K, Chamaret $S$, et al. Human immunodeficiency virus type 2 infection associated with AIDS in West Africa. $N$ Engl J Med 1987; 316: 1180-1185.

8. Barre-Sinoussi F, Chermann JC, Rey F, et al. Isolation of a T-lymphotropic retrovirus from a patient at risk for acquired immune deficiency syndrome (AIDS). Science 1983; 220: 868-871.

9. Kong LI, Lee SW, Kappes JC, et al. West African HIV-2-related human retrovirus with attenuated cytopathicity. Science 1988; 240: 1525-1529.

10. Chaisson RE, Volberding PA Clinical manifestations of HIV infection. In: Mandell GL, Douglas RG,Jr., Bennett JE, eds. Principles and Practice of Infectious Diseases, 3rd edn. New York: Churchill Livingstone, 1990; 1059.

11. Belman AL, Diamond G, Dickson D, et al. Pediatric acquired immunodeficiency syndrome. Neurologic syndromes [published erratum appears in Am J Dis Child 1988 May; 142(5):507]. Am J Dis Child 1988; 142: 29-35.

12. Levy RM, Rosenbloom S, Perrett LV Neuroradiologic findings in AIDS: a review of 200 cases. Am J Roentgenol 1986; 147: 977 983.

13. Gabuzda DH, Hirsch MS. Neurologic manifestations of infection with human immunodeficiency virus. Clinical features and pathogenesis. Ann Intern Med 1987; 107: 383-391.

14. Johnson RT, McArthur JC, Narayan O. The neurobiology of human immunodeficiency virus infections. FASEB J 1988; 2: 2970-2981.

15. Giulian D, Vaca K, Corpuz M. Brain glia release factors with opposing actions upon neuronal survival. J Neurosci 1993; 13: 29-37.

16. McArthur JC. Neurologic manifestations of AIDS. Medicine 1987; 66: 407-437.

17. Janssen RS, Cornblath DR, Epstein LG, et al. Nomenclature and research case definitions for neurologic manifestations of human immunodeficiency virus-type 1 (HIV-1) infection. Neurology 1991; 41: 778-785

18. Navia BA, Cho E-S, Petito CK, Price RW. The AIDS dementia complex: II. Neuropathology. Ann Neurol 1986; 19: 525-535.

19. Navia BA, Jordan BD, Price RW The AIDS dementia complex: I. Clinical features. Ann Neurol 1986; 19: 517-524.

20. Janssen RS, Nwanyanwu OC, Selik RM, Stehr-Green JK. Epidemiology of human immunodeficiency virus encephalopathy in the United States. Neurology 1992; 42: 1472-1476.

21. McArthur JC, Cohen BA, Selnes OA, et al. Low prevalence of neurological and neuropsychological abnormalities in otherwise healthy HIV-1-infected individuals: results from the multicenter AIDS Cohort Study. Ann Neurol 1989; 26: 601-611.
22. Goethe KE, Mitchell JE, Marshall DW, et al. Neuropsychological and neurological function of human immunodeficiency virus seropositive asymptomatic individuals. Arch Neurol 1989; 46: 129-133.

23. Selnes OA, Miller E, McArthur J, et al. HIV-I infection: no evidence of cognitive decline during the asymptomatic stages. The Multicenter AIDS Cohort Study [see comments]. Neurology 1990; 40: 204-208.

24. McArthur JC, Hoover DR, Bacellar $\mathrm{H}$, et al. Dementia in AIDS patients: incidence and risk factors. Neurology 1993; 43: 22452252.

25. Price RW, Brew BJ. The AIDS dementia complex. J Infect Dis 1988; 158: 1079-1083.

26. Tross S, Price RW, Navia B, et al. Neuropsychological characterization of the AIDS dementia complex: a preliminary report. AIDS 1988; 2: 81-88.

27. Power C. Selnes OA, Grim JA, McArthur JC. The HIV dementia scale: a rapid screening test. J Acquir Immune Defic Syndr Hum Retrovir 1995; 8: 273-278.

28. Folstein MF, Folstein SE, McHugh PR. Mini-mental state. A practical method for grading the cognitive state of patients for the clinician. J Psychiatr Res 1975; 12: 189-198.

29. Currie J, Benson E, Ramsden B, Perdices M, Cooper D. Eye movement abnormalities as a predictor of the acquired immunodeficiency syndrome dementia complex [see comments]. Arch Neurol 1988; 45: 949-953.

30. McArthur JC, Sipos E, Cornblath DR, et al. Identification of mononuclear cells in CSF of patients with HIV infection. Neurology 1989; 39: 66-70.

31. Royal W, Selnes OA, Concha M, Nance-Sproson TE, McArthur JC. Cerebrospinal fluid HIV-1 p24 antigen levels in HIV-1-related dementia. Ann Neurol 1994; 36: 32-39.

32. Post MJ, Tate LG, Quencer RM, et al. CT, MR, and pathology in HIV encephalitis and meningitis. Am J Roentgenol 1988; 151: 373-380.

33. LaFrance ND, Pearlson GD, Schaerf FW, et al. I-123 IMP-SPECT in HIV-related dementia. Ad Funct Neuroimaging 1988; 1: 9-15.

34. Koralnik IJ, Beaumanoir A, Hausler R, et al. A controlled study of early neurologic abnormalities in men with asymptomatic human immunodeficiency virus infection [published erratum appears in N Engl J Med 1990 Dec 13;323(24): 1716] [see comments]. N Engl J Med 1990; 323: 864-870.

35. Holland NR, Power C, Mathews VP, et al. Cytomegalovirus encephalitis in acquired immunodeficiency syndrome (AIDS) Neurology 1994; 44: 507-514.

36. Glass JD, Wesselingh SL, Selnes OA, McArthur JC. Clinical-neuropathologic correlation in HIV-associated dementia. Neurology 1993; 43: 2230-2237.

37. Gray F, Gherardi R, Scaravilli F. The neuropathology of the acquired immune deficiency syndrome (AIDS). A review. Brain 1988; $111: 245-266$.

38. Davis LE, Hjelle BL, Miller VE, et al. Early viral brain invasion in iatrogenic human immunodeficiency virus infection. Neurology 1992; 42: 1736-1739.

39. Gray F, Lescs MC, Keohane C, et al. Early brain changes in HIV infection: neuropathological study of II HIV seropositive, nonAIDS cases. J Neuropathol Exp Neurol 1992; 51:177-185.

40. Budka H. Neuropathology of human immunodeficiency virus infection. Brain Pathol 1991; 1: 163-175.

41. Vinters HV, Anders KH. Neuropathology of AIDS. Boca Raton: CRC Press, 1990; 197.

42. Sharer LR. Pathology of HIV-1 infection of the central nervous system. A review. J Neuropathol Exp Neurol 1992; 51: 3-11.

43. Everall IP. Luthert PJ, Lantos PL. Neuronal loss in the frontal cortex in HIV infection [see comments]. Lancet 1991; 337: 1119. 1121

44. Gray F, Haug H, Chimelli L, et al. Prominent cortical atrophy with neuronal loss as correlate of human immunodeficiency virus encephalopathy. Acta Neuropathol (Berl) 1991; 82: 229-233.

45. Wiley CA, Schrier RD, Nelson JA, Lampert PW, Oldstone MBA. Cellular localization of human immunodeficiency virus infection within the brains of acquired immune deficiency syndrome patients. Proc Natl Acad Sci USA 1986; 83: 7089-7093. 
46. Shaw GM, Harper ME, Hahn BH, et al. HTLV-IIl infection in brains of children and adults with AIDS encephalopathy. Science 1985; 227: 177-182.

47. Koenig S, Gendelman HE, Orenstein JM, et al. Detection of AIDS virus in macrophages in brain tissue from AIDS patients with encephalopathy. Science 1986; 233: 1089-1093.

48. Kure K, Weidenheim KM, Lyman WD, Dickson DW. Morphology and distribution of HIV-1 gp4l-positive microglia in subacute AIDS encephalitis. Pattern of involvement resembling a multisystem degeneration. Acta Neuropathol (Berl) 1990; 80: 393400

49. Pumarola-Sune T, Navia BA, Cordon-Cardo C, Cho ES, Price RW. HIV antigen in the brains of patients with the AIDS dementia complex. Ann Neurol 1987; 21: 490-496.

50. Watkins BA, Dorn HH, Kelly WB, et al. Specific tropism of HIV-I for microglial cells in primary human brain cultures. Science 1990; 249: 549-553.

51. Yamada M, Watabe K, Saida T, Kim SU. Increased susceptibility of human fetal astrocytes to human T-lymphotropic virus type in culture. J Neuropathol Exp Neurol 1991; 50: 97-107.

52. Vazeux R, Lacroix-Ciaudo C, Blanche S, et al. Low levels of human immunodeficiency virus replication in the brain tissue of children with severe acquired immunodeficiency syndrome encephalopathy. Am J Pathol 1992; 140: 137-144.

53. Nuovo GJ, Gallery F, MacConnell P, Braun A. In situ detection of polymerase chain reaction-amplified HIV-I nucleic acids and tumor necrosis factor-alpha RNA in the central nervous system. Am J Pathol 1994; 144: 659-666.

54. Wiley CA, Masliah E, Morey M, et al. Neocortical damage during HIV infection. Ann Neurol 1991; 29: 651-657.

55. Masliah E, Ge N, Morey M, et al. Cortical dendritic pathology in human immunodeficiency virus encephalitis [see comments]. Lab Invest 1992; 66: 285-291.

56. Masliah E, Ge N, Achim CL, Hansen LA, Wiley CA. Selective neuronal vulnerability in HIV encephalitis. J Neuropathol Exp Neurol 1992; 51:585-593

57. Portegies $P$, de Gans J, Lange JM, et al. Declining incidence of AIDS dementia complex after introduction of zidovudine treatment [published erratum appears in Br Med J 1989 Nov 4; 299(6708): 1141] [see comments]. Br Med J 1989; 299: 819 . 821.

58. Schmitt FA, Bigley JW, McKinnis R, et al. Neuropsychological outcome of zidovudine (AZT) treatment of patients with AIDS and AIDS-related complex. N Engl J Med 1988; 319: 1573 . 1578 .

59. Sidtis JJ, Gatsonis C, Price RW, et al. Zidovudine treatment of the AIDS dementia complex: results of a placebo-controlled trial. AIDS Clinical Trials Group. Ann Neurol 1993; 33: 343-349.

60. Pizzo PA, Eddy J, Falloon J, et al. Effect of continuous intravenous infusion of zidovudine (AZT) in children with symptomatic HIV infection [see comments]. N Engl J Med 1988; 319: 889-896.

61. Dreyer EB, Kaiser PK, Offermann JT, Lipton SA. HIV-1 coat protein neurotoxicity prevented by calcium channel antagonists. Science 1990; 248: 364-367.

62. Heyes MP, Brew BJ, Martin A, et al. Quinolinic acid in cerebrospinal fluid and serum in HIV-1 infection: relationship to clinical and neurological status. Ann Neurol 1991; 29: 202-209.

63. Tyor WR, Glass JD, Griffin JW, et al. Cytokine expression in the brain during the acquired immunodeficiency syndrome. Ann Neurol 1992: 31: 349-360.

64. Wesselingh SL, Power C, Glass JD, et al. Intracerebral cytokine messenger RNA expression in acquired immunodeficiency syndrome dementia. Ann Neurol 1993; 33: 576-582.

65. Li Y, Kappes JC, Conway JA, et al. Molecular characterization of human immunodeficiency virus type 1 cloned directly from uncultured human brain tissue: identification of replicationcompetent and -defective viral genomes. J Virol 1991; 65: 3973 3985 .

66. Li Y, Hui H, Burgess CJ, et al. Complete nucleotide sequence, genome organization, and biological properties of human immunodeficiency virus type 1 in vivo: evidence for limited defectiveness and complementation. J Virol 1992; 66: 6587-6600.

67. Pang S, Vinters HV, Akashi T, O'Brien WA, Chen ISY. HIV-1 Env sequence variation in brain tissue of patients with AIDSrelated neurologic disease. J Acquir Immune Defic Syndr 199!; 4: 1082-1092.
68. Epstein LG, Kuiken C. Blumberg BM, et al. HIV-1 V3 domain variation in brain and spleen of children with AIDS: tissue-specific evolution within host-determined quasispecies. Virology 1991; 180: 583-590.

69. Giulian D, Vaca K, Noonan C. Secretion of neurotoxins by mononuclear phagocytes infected with HIV-1. Science 1990: 250: 1593-1596.

70. Haase AT. Pathogenesis of lentivirus infections. Nature 1986; 322 : 130-136.

71. Dalgleish AG, Beverley PC, Clapham PR, et al. The CD4 (T4) antigen is an essential component of the receptor for the AIDS retrovirus. Nature 1984; 312: 763-767.

72. Harouse JM, Bhat S, Spitalnik SL, et al. Inhibition of entry of HIV-1 in neural cell lines by antibodies against galactosyl ceramide. Science 1991; 253: 320-323.

73. Ma M, Geiger J, Nath A. Characterization of a novel binding site for the human immunodeficiency virus type 1 envelope protein gp 120 on fetal astrocytes. J Virol 1994; 68: 6824-6828.

74. Moses AV, Bloom FE, Pauza CD, Nelson JA. Human immunodeficiency virus infection of human brain capillary endothelial cells occurs via a CD4/galactosylceramide-independent mechanism. Proc Natl Acad Sci USA 1993; 90: 10474-10478.

75. Chesebro B, Nishio J, Perryman S, et al. Identification of human immunodeficiency virus envelope gene sequences influencing viral entry into CD4-positive HeLa cells, T-leukemia cells, and macrophages. J Virol 1991; 65: 5782-5789.

76. Sharpless NE, O'Brien WA, Verdin E, et al. Human immunodeficiency virus type 1 tropism for brain microglial cells is determined by a region of the env glycoprotein that also controls macrophage tropism. J Virol 1992; 66: 2588-2593.

77. Shioda T, Levy JA, Cheng-Mayer C. Macrophage and T cell-line tropisms of HIV-1 are determined by specific regions of the envelope gp 120 gene. Nature 1991; 349: 167-169.

78. Koyanagi Y, Miles S, Mitsuyasu RT, et al. Dual infection of the central nervous system by AIDS viruses with distinct cellular tropisms. Science 1987: 236: 819-822.

79. Georgsson G, Houwers DJ, Pálsson PA, Pétursson G. Expression of viral antigens in the central nervous system of visna-infected sheep: an immunohistochemical study on experimental visna induced by virus strains of increased neurovirulence. Acta Neuropathol 1989; 77: 299-306.

80. Sharma DP, Zink MC, Anderson M, et al. Derivation of neurotropic simian immunodeficiency virus from exclusively lymphocytetropic parental virus: pathogenesis of infection in macaques. J Virol 1992; 66: 3550-3556.

81. Lynch WP, Czub S, McAtee FJ, Hayes SF, Portis JL. Murine retrovirus-induced spongiform encephalopathy: productive infection of microglia and cerebellar neurons in accelerated CNS disease. Neuron 1991; 7: 365-379.

82. Szurek PF, Floyd E, Yuen PH, Wong PKY. Site-directed mutagenesis of the codon for lle-25 in $\mathrm{gPr} 80^{\mathrm{cm}}$ alters the neurovirulence of $t s 1$, a mutant of Moloney murine leukemia virus TB. J Virol 1990; 64: 5241-5429.

83. Lackner AA, Dandekar S, Gardner MB. Neurobiology of simian and feline immunodeficiency virus infections. Brain Pathol 1991; 1: 201-212.

84. Nathanson N, Georgsson G, Palsson PA, et al. Experimental visna in Icelandic sheep: the prototype lentiviral infection. Rev Infect Dis 1985: 7: 75-82.

85. Power C, McArthur JC, Johnson RT, et al. Demented and nondemented patients with AIDS differ in brain-derived human immunodeficiency virus type 1 envelope sequences. J Virol 1994; 68: 4643-4649.

86. Giulian D, Wendt E, Vaca K, Noonan CA. The envelope glycoprotein of human immunodeficiency virus type I stimulates release of neurotoxins from monocytes. Proc Natl Acad Sci USA 1993; 90: 2769-2773

87. Power C, McArthur JC, Johnson RT, et al. Distinct HIV-I em' sequences are associated with neurotropism and neurovirulence. Curr Top Microbiol Immunol; (In Press).

88. Merrill JE, Chen IS. HIV-1, macrophages, glial cells, and cytokines in AIDS nervous system disease. FASEB J 1991: 5: $2391-2397$ 
89. Lipton SA. HIV-related neurotoxicity. Brain Pathol 1991; 1: 193199.

90. Hill JM, Mervis RF, Avidor R, Moody TW, Brenneman DE. HIV envelope protein-induced neuronal damage and retardation of behavioral development in rat neonates. Brain Res 1993; 603 : 222-233.

91. Dawson VL, Dawson TM, Uhl GR, Snyder SH. Human immunodeficiency virus type 1 coat protein neurotoxicity mediated by nitric oxide in primary cortical cultures. Proc Natl Acad Sci USA 1993; 90: 3256-3259.

92. Rosenberg ZF, Fauci AS. Immunopathogenic mechanisms of HIV infection: cytokine induction of HIV expression. Immunol Today 1990; I1: 176-180.

93. Power C, Kong P-A, Crawford TO, et al. Cerebral white matter changes in acquired immunodeficiency syndrome dementia: alterations of the blood-brain barrier. Ann Neurol 1993; 34: 339350.

94. Merrill JE, Koyanagi Y, Chen IS. Interleukin-I and tumor necrosis factor alpha can be induced from mononuclear phagocytes by human immunodeficiency virus type 1 binding to the CD4 receptor. J Virol 1989; 63: 4404-4408.

95. Mintz M, Rapaport R, Oleske JM, et al. Elevated serum levels of tumor necrosis factor are associated with progressive encephalopathy in children with acquired immunodeficiency syndrome. Am J Dis Child 1989; 143: 771-774.

96. Genis P, Jett M, Bernton EW, et al. Cytokines and arachidonic metabolites produced during human immunodeficiency virus (HIV)-infected macrophage-astroglia interactions: implications for the neuropathogenesis of HIV disease. J Exp Med 1992; 176: 1703-1718.

97. Griffin DE, Wesselingh SL, McArthur JC. Elevated central nervous system prostaglandins in human immunodeficiency virusassociated dementia. Ann Neurol 1994; 35: 592-597.

98. Selmaj KW, Raine CS. Tumor necrosis factor mediates myelin and oligodendrocyte damage in vitro. Ann Neurol 1988; 23: 339. 346.

99. Quagliarello VJ, Wispelwey B, Long WJ,Jr., Scheld WM. Recombinant human interleukin- 1 induces meningitis and bloodbrain barrier injury in the rat. Characterization and comparison with tumor necrosis factor. J Clin Invest 1991; 87: 1360-1366.

100. Ramilo O, Saez-Llorens X, Mertsola J, et al. Tumor necrosis factor alpha/cachectin and interleukin 1 beta initiate meningeal inflammation. J Exp Med 1990; 172: 497-507.
101. Saukkonen K, Sande S, Cioffe C, et al. The role of cytokines in the generation of inflammation and tissue damage in experimental gram-positive meningitis. J Exp Med 1990; 171: 439-448.

102. Rhodes RH. Evidence of serum-protein leakage across the bloodbrain barrier in the acquired immunodeficiency syndrome. J Neuropathol Exp Neurol 1991; 50: 171-183.

103. Petito CK, Cash KS. Blood-brain barrier abnormalities in the acquired immunodeficiency syndrome: immunohistochemical localization of serum proteins in postmortem brain. Ann Neurol 1992; 32: 658-666.

104. McArthur JC, Nance-Sproson TE, Griffin DE, et al. The diagnostic utility of elevation in cerebrospinal fluid beta 2-microglobulin in HIV-1 dementia. Multicenter AIDS Cohort Study. Neurology 1992; 42: 1707-1712

105. Smith TW, DeGirolami U, Henin D, Bolgert F, Hauw JJ. Human immunodeficiency virus (HIV) leukoencephalopathy and the microcirculation. J Neuropathol Exp Neurol 1990; 49: 357-370.

106. Adams DH, Shaw S. Leucocyte-endothelial interactions and regulation of leucocyte migration. Lancet 1994; 343: 831-836.

107. Power C, Kong PA, McArthur JC, et al. Alterations in the bloodbrain barrier associated with HIV dementia. Clin Neuropathol 1993; 3: 56.

108. Dow SW, Poss ML, Hoover EA. Feline immunodeficiency virus: a neurotropic lentivirus. J Acquir Immune Defic Syndr 1990; 3: 658-668

109. Tyor WR, Power C, Gendelman HE, Markham RB. A model of human immunodeficiency virus encephalitis in scid mice. Proc Natl Acad Sci USA 1993; 90: 8658-8662.

110. Corboy JR, Buzy JM, Zink MC, Clements JE. Expression directed from HIV long terminal repeats in the central nervous system of transgenic mice. Science 1992; 258: 1804-1808.

111. Toggas SM, Masliah E, Rockenstein EM, et al. Central nervous system damage produced by expression of the HIV-I coat protein gp 120 in transgenic mice. Nature 1994; 367: 188-193.

112. Buller RS, Wehrly K, Portis JL, Chesebro B. Host genes conferring resistance to a central nervous system disease induced by a polytropic recombinant Friend murine retrovirus. J Virol 1990; 64: $493-498$.

113. Chesebro B, Miyazawa M, Britt WJ. Host genetic control of spontaneous and induced immunity to Friend murine retrovirus infection. Ann Rev Immunol 1990; 8: 477-499.

114. Rassart E, Nelbach L, Jolicoeur P. Cas BrE murine leukemia virus: sequencing of the paralytogenic region of its genome and derivation of specific probes to study its origin and the structure of its recombinant genomes in leukemic tissues. J Virol 1986; 60: $910-919$. 